\title{
Efek Hepatoprotektor Andrographolide Terhadap Aktivitas Alanin Aminotransferase Dalam Serum Rattus norvegicus Jantan
Galur Wistar Yang Diinduksi Karbon Tetraklorida
}

\author{
Dewinta Putri Utami $^{1}$, Andriani2 ${ }^{*}$, Mardhia ${ }^{3}$, Virhan Novianry ${ }^{2}$, Mistika Zakiah ${ }^{4}$ \\ ${ }^{1}$ Medical School, Faculty of Medicine, Tanjungpura University \\ ${ }^{2}$ Department of Biochemistry, Tanjungpura University \\ ${ }^{3}$ Department of Microbiology, Tanjungpura University \\ ${ }^{4}$ Department of Histology, Tanjungpura University
}

\begin{tabular}{|c|c|}
\hline Article info & Abstract \\
\hline History & Andrographolide is a diterpenoid bioethanol that effectively prevent liver \\
\hline Submission: $17-10-2019$ & injury by reducing liver oxidative stress response. The research was \\
\hline Review: $20-10-2020$ & randomized experimental design with pretest-posttest design. Thirty male \\
\hline Accepted: 19-01-2021 & wistar rats was randomly divided into 6 groups, normal control, negative \\
\hline $\begin{array}{l}\text { "Email: } \\
\text { drvirhannovianry@gmail.com }\end{array}$ & $\begin{array}{l}\text { control }\left(0,2 \mathrm{ml} \mathrm{CCl}_{4}\right) \text {, and positive control }(500 \mathrm{mg} / \mathrm{kgBW} \text { curcumin }) \text {, dose } \\
I(50 \mathrm{mg} / \mathrm{kgBW}) \text {, dose II }(100 \mathrm{mg} / \mathrm{kgBW}) \text {, dose III }(200 \mathrm{mg} / \mathrm{kgBW}) \text { given for }\end{array}$ \\
\hline & 8 days and induced by $0,2 \mathrm{ml} \mathrm{CCl}_{4}$ on the first day. Data was analyzed by \\
\hline DOI: $10.33096 /$ jffi.v8i1.582 & $\begin{array}{l}\text { One-Way Anova test, LSD Post-Hoc test and paired } T \text { test. All groups } \\
\text { induced by CCl4 shows elevated of ALT activity. The posttest results shows }\end{array}$ \\
\hline Keywords: & significant differences of ALT activity between groups $(p<0,05)$. \\
\hline Andrographolide, $\mathrm{CCl}_{4}$, & Andrographolide shows hepatoprotector effect by decrease the activity of \\
\hline $\begin{array}{l}\text { hepatoprotector, alanine } \\
\text { aminotransferase }\end{array}$ & $\begin{array}{l}\text { ALT in male wistar rats induced by } \mathrm{CCl}_{4} \text {. The effective dose of } \\
\text { andrographolide is } 200 \mathrm{mg} / \mathrm{kgBW} \text {. }\end{array}$ \\
\hline
\end{tabular}

\section{Pendahuluan}

Hepar merupakan organ metabolik terbesar yang memiliki peran terpenting dalam proses biokimia tubuh (Torotra and Derrickson, 2014). Salah satu fungsi hepar adalah mendetoksifikasi atau mendegradasi zat-zat sisa dalam tubuh dan hormon, serta obat-obatan dan senyawa asing lainnya (Sherwood, 2014). Maka dari itu, hepar sangat rentan terhadap paparan berbagai zat metabolik, racun, mikroba, dan peredaran darah yang dalam beberapa kasus dapat menyebabkan kerusakan hepar (Kumar, Abbas and Aster, 2013). Kerusakan pada hepar menyebabkan sel hepatosit melepaskan alanin aminotransferase (ALT) ke dalam ruang ekstraseluler dan selanjutnya ke dalam darah, sehingga kadar ALT dalam serum meningkat. Salah satu senyawa yang diketahui dapat menginduksi kerusakan hepar dan digunakan sebagai model untuk mempelajari kerusakan hepar pada penelitian adalah karbon tetraklorida (Departemen Kesehatan RI, 2007; Sonderup, 2011).

Untuk meningkatkan pertahanan terhadap efek radikal bebas pada hepar, diperlukan antioksidan dari luar tubuh atau eksogen. Senyawa yang saat ini telah terbukti memiliki efek sebagai antioksidan eksogen ialah kurkumin. Kurkumin merupakan senyawa polifenol alami yang diekstraksi dari kunyit (Curcuma longa Linn.) yang menunjukkan aktivitas antioksidan, antiinflamasi, antiviral, antimikroba, dan antikanker (Ratner et al., 2008).

Selain kurkumin, penelitian terbaru menunjukkan bahwa terdapat salah satu senyawa yang diduga memiliki efek sebagai antioksidan eksogen, yakni andrographolide. Andrographolide adalah senyawa bioetanol diterpenoid yang berasal dari ekstrak tanaman obat Sambiloto (Andrographis paniculata Ness), yang secara tradisional digunakan di Asia untuk mengobati demam, batuk, tuberkulosis, gigitan ular, infeksi saluran pernapasan, dan infeksi saluran kemih. Studi in vivo dan in vitro menunjukkan bahwa A.paniculata dan andrographolide memiliki aktivitas antioksidan, anti inflamasi, anti aterosklerosis, anti kanker, dan tindakan hipoglikemik (Fujii et al., 2010).

Berdasarkan latar belakang tersebut, peneliti bermaksud melakukan penelitian mengenai efek hepatoprotektor andrographolide terhadap aktivitas ALT dalam serum Rattus norvegicus jantan galur Wistar yang diinduksi $\mathrm{CCl}_{4}$ dengan membandingkannya pada senyawa kurkumin.

\section{Metode Penelitian \\ II.1 Alat dan Bahan}

Alat-alat yang digunakan dalam penelitian ini adalah kandang tikus, spuit injeksi dan oral, sonde lambung, spektrofotometer (Genesys 10S UV-Vis Spectophotometry), sentrifuge, timbangan obat, timbangan hewan, mikropipet, kuvet 
disposable, microtube $2 \mathrm{ml}$, tip biru, tip kuning, tip putih.

Bahan-bahan yang digunakan dalam penelitian ini adalah tikus Rattus norvegicus jantan galur Wistar, berumur 2-3 bulan dengan berat badan 120-200 gram, andrographolide ${ }^{\circledR}$ (PT. SigmaAldrich, Jerman), kurkumin, $\mathrm{CCl}_{4}$ (Merck, German), carboxymethyl cellulose (CMC), olive oil, aquades $100 \mathrm{ml}$, makanan standar, dan reagen AnalyticonFluitest ${ }^{\circledR}$ (DiaSys, Jerman).

\section{II.2 Metode}

Tikus yang digunakan adalah tikus putih (Rattus norvegicus) jantan galur Wistar, berumur 23 bulan dengan berat badan tikus 120-200 gram sebanyak 30 ekor tikus yang dibagi kedalam 6 kelompok perlakuan.

Kelompok I merupakan kelompok perlakuan normal, diberikan makanan standar selama 8 hari. Kelompok II merupakan kontrol negatif, diberikan $\mathrm{CCl}_{4}$ dan makanan standar. Kelompok III merupakan kontrol positif, diberikan $\mathrm{CCl}_{4}$ dan kurkumin. Kelompok IV-VI merupakan kelompok uji dosis, diberikan $\mathrm{CCl}_{4}$ dan andrographolide. $\quad \mathrm{CCl}_{4} \quad$ diberikan secara intraperitoneal dalam satu kali pemberian $(0,2$ $\mathrm{ml} / 200 \mathrm{gBB}$ dicampurkan dalam olive oil 1:1) pada hari pertama. Kurkumin diberikan selama 8 hari secara intragastrical dengan dosis $500 \mathrm{mg} / \mathrm{kgBB}$ disuspensikan ke dalam 0,5\% methyl cellulose. Andrographolide diberikan selama 8 hari secara intragastrical dengan dosis $50 \mathrm{mg} / \mathrm{kgBB}, 100$ $\mathrm{mg} / \mathrm{kgBB}$, dan $200 \mathrm{mg} / \mathrm{kgBB}$ disuspensikan ke dalam $0,5 \%$ methyl cellulose.

Aktivitas ALT diukur pada hari ke-2 untuk mengamati kerusakan hepar yang disebabkan oleh CCl4 dan setelah uji dosis hari ke-8 untuk mengamati efek andrographolide. Darah diambil melalui vena ekor. Sampel darah dibiarkan membeku selama 30-60 menit. Kemudian disentrifuge dengan kecepatan $4000 \mathrm{rpm}$ dan suhu $15^{\circ} \mathrm{C}$ selama 15 menit untuk memisahkan serum dari darah. Serum darah ditambahkan dengan reagen AnalyticonFluitest ${ }^{\circledR}$ dan dibaca menggunakan spektofotometri dengan panjang gelombang $340 \mathrm{~nm}$. Data yang diperoleh dianalisis secara statistik dengan uji $\mathrm{T}$ berpasangan dan One Way Anova. Jika terdapat perbedaan bermakna, dilanjutkan dengan Post hoc Least Significant Differences (LSD) dengan tingkat kepercayaan $95 \%$ ( $\alpha$ ) 0,05. Penelitian ini telah lolos kaji etik dari Komite Etik Fakultas Kedokteran Universitas Tanjungpura dengan nomor 2747/UN22.9/DL/2018.

\section{Hasil dan Pembahasan \\ III.1 Hasil}

Pemberian karbon tetraklorida $\left(\mathrm{CCl}_{4}\right)$ secara intraperitoneal pada hewan coba menyebabkan terjadinya kerusakan sel hepar yang ditandai dengan peningkatan aktivitas spesifik enzim ALT (Gambar 1). Bila dibandingkan dengan kelompok normal, pada kelompok II-VI terjadi peningkatan aktivitas spesifik enzim ALT akibat pemberian $\mathrm{CCl}_{4}$. Pemberian andrographolide (50, $100,200 \mathrm{mg} / \mathrm{kgBB}$ ) menunjukkan adanya perbaikan dari sel hepar yang rusak, ditandai dengan adanya penurunan aktivitas spesifik enzim ALT. Pemberian $200 \mathrm{mg} / \mathrm{kgBB}$ andrographolide menunjukkan adanya penurunan aktivitas spesifik enzim ALT yang signifikan (Gambar 2). Pemberian kurkumin juga menunjukkan adanya penurunan aktivitas spesifik enzim ALT. Perbedaan aktivitas spesifik enzim ALT antara pretest dan posttest ditunjukkan pada Tabel 1 .

Tabel 1. Aktivitas spesifik enzim ALT (Mean \pm SD)

\begin{tabular}{|c|c|c|}
\hline \multirow{2}{*}{ Kelompok } & \multicolumn{2}{|c|}{ ALT Enzyme Activity (Mean \pm SD) } \\
\hline & Pre-Test & Post-Test \\
\hline Kelompok I & $28,426 \pm 0,44679$ & $29,540 \pm 0,57480$ \\
\hline Kelompok II $^{+}$ & $53,474 \pm 0,64104^{\times}$ & $42,826 \pm 0,78223^{*}$ \\
\hline Kelompok III ${ }^{+}$ & $54,752 \pm 1,04619^{\times}$ & $25,664 \pm 1,55548^{* * * *}$ \\
\hline Kelompok IV + & $55,040 \pm 1,37027^{\times}$ & $42,208 \pm 1,15584^{* / * * *}$ \\
\hline Kelompok V + & $54,752 \pm 1,14266^{\times}$ & $39,446 \pm 0,88996^{* / * * / * * *}$ \\
\hline Kelompok VI ${ }^{+}$ & $53,886 \pm 0,60805^{\times}$ & $23,970 \pm 1,10878^{* / * * * * * * *}$ \\
\hline
\end{tabular}

Keterangan: ANOVA, $\mathrm{p}=0,000, \mathrm{LSD},{ }^{\times} \mathrm{p}<0,05$ vs Kelompok normal (pre-test). ANOVA, $\mathrm{p}=0,000 ; \mathrm{LSD},{ }^{*} \mathrm{p}<0,05$ vs Kelompok normal, ${ }^{* *} \mathrm{p}<0,05$ vs Kelompok negatif, ${ }^{* * *} \mathrm{p}<0,05$ vs Kelompok positif (post-test). Uji T berpasangan, ${ }^{+} \mathrm{p}$ $<0,05$. 


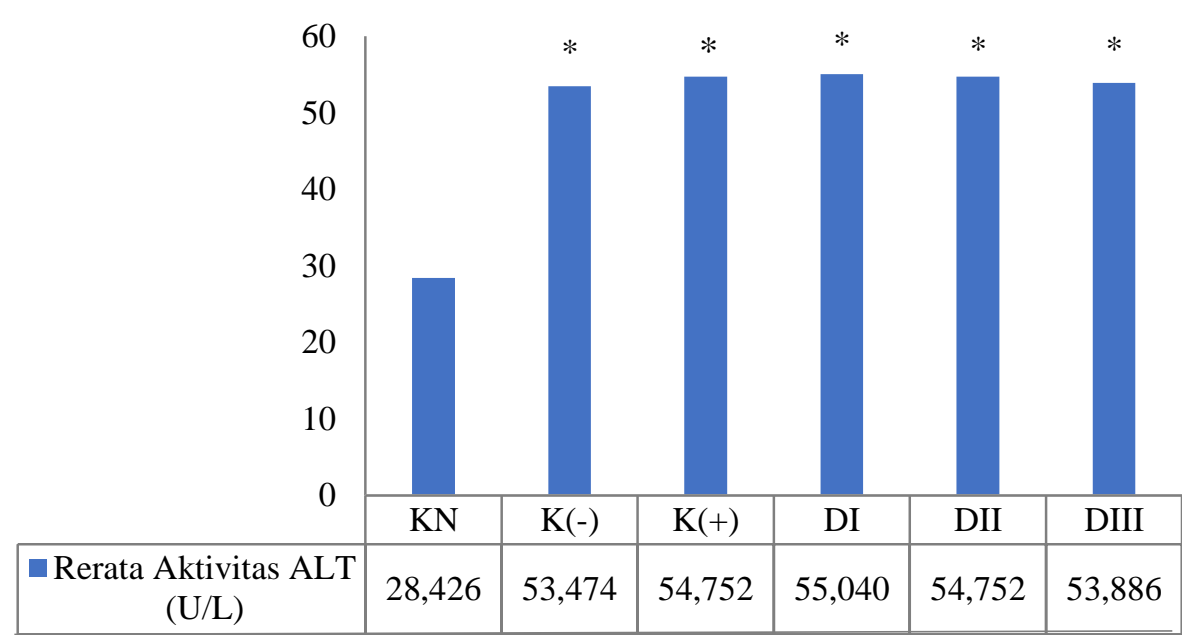

Gambar 1. Rerata aktivitas enzim alanin aminotransferase (ALT) serum sebelum perlakuan (Pretest) (ANOVA, $\mathrm{p}=0,000$, LSD, ${ }^{*} \mathrm{p}<0,05$ vs KN). (Ket; KN: Kontrol normal, $\mathrm{K}(-)$ : Kontrol negatif, $\mathrm{K}(+)$ : Kontrol positif, DI :

Uji dosis I (50 mg/kgBB), DII : Uji dosis II (100 mg/kgBB), DIII : Uji dosis III (200 mg/kgBB))

Pengukuran aktivitas enzim ALT sebelum perlakuan (pretest) dilakukan 1 hari setelah pemberian induksi $\mathrm{CCl}_{4}$. Gambar 1 menunjukkan hasil rerata aktivitas enzim ALT pretest pada kelompok normal $(28,426 \pm 0,44679)$ yang masih dalam rentang normal. Hasil rerata aktivitas enzim ALT pretest pada kelompok negatif $(53,474 \pm 0,64104)$, kelompok positif $(54,752 \pm 1,04619)$, kelompok uji dosis I $(55,040 \pm 1,37027)$, kelompok uji dosis II
$(54,752 \pm 1,14266)$, dan uji dosis III $(53,886 \pm 0,60805)$ mengalami peningkatan apabila dibandingkan dengan kelompok normal. Hal ini menunjukkan bahwa pemberian induksi $\mathrm{CCl}_{4}$ pada kelompok negatif, kelompok positif, kelompok uji dosis I, kelompok uji dosis II, dan kelompok uji dosis III menyebabkan terjadinya peningkatkan aktivitas enzim ALT dibandingkan aktivitas ALT pada kelompok normal yang tidak diberikan $\mathrm{CCl}_{4}$ dan hanya diberikan pangan standar.

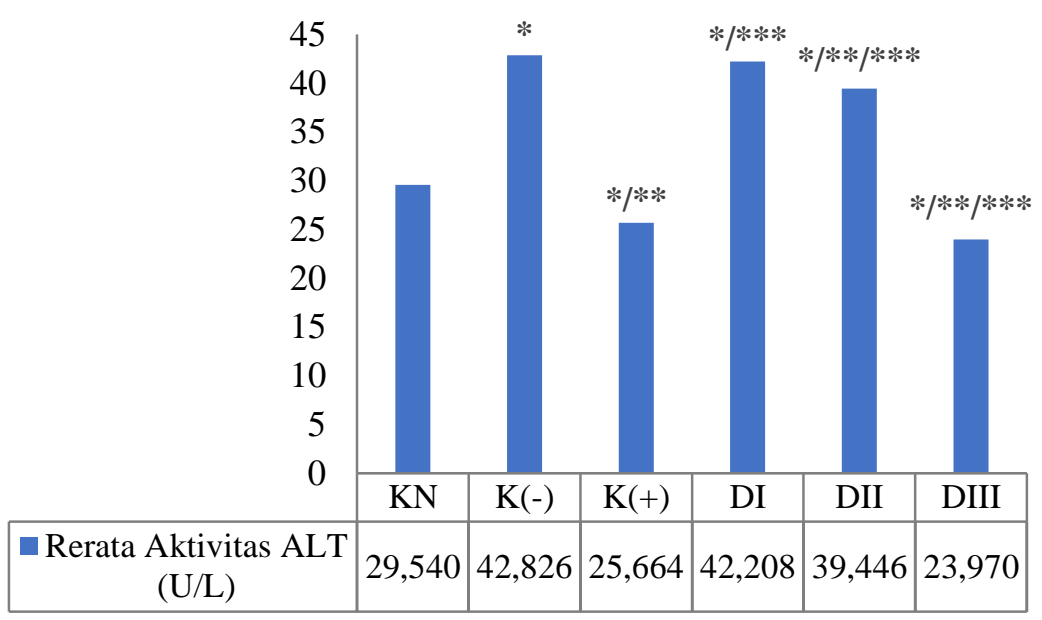

Gambar 2. Rerata aktivitas enzim alanin aminotransferase (ALT) setelah perlakuan (Posttest) (ANOVA, $\mathrm{p}=0,000 ; \mathrm{LSD}, *_{\mathrm{p}}<0,05$ vs KN, $* * \mathrm{p}<0,05$ vs $\mathrm{K}(-)$, ***p $<0,05$ vs $\mathrm{K}(+)$ ). (Ket; KN: Kontrol normal, $\mathrm{K}(-)$ : Kontrol negatif, $\mathrm{K}(+)$ : Kontrol positif, DI : Uji dosis I (50 mg/kgBB), DII : Uji dosis II (100 mg/kgBB), DIII : Uji dosis III (200 mg/kgBB))

Pengukuran aktivitas enzim ALT setelah perlakuan (posttest) dilakukan setelah 8 hari pemberian kurkumin pada kelompok positif dan andrographolide pada kelompok uji dosis I, kelompok uji dosis II, kelompok uji dosis III, serta pemberian makanan standar pada kelompok negatif dan kelompok normal. Pada Tabel 1 dan Gambar 2 menunjukkan penurunan rerata aktivitas enzim ALT posttest pada kelompok positif yang diberikan kurkumin, kelompok uji dosis I, kelompok uji dosis II, dan kelompok uji dosis III yang diberikan andrographolide, maupun kelompok negatif yang hanya diberikan makanan standar. Hal ini menunjukkan bahwa pemberian andrographolide menurunkan aktivitas enzim ALT dan kelompok uji dosis III merupakan kelompok yang memiliki kemampuan menurunkan aktivitas enzim ALT paling baik dibandingkan kelompok lainnya. 


\section{III.2 Pembahasan}

Semua kelompok yang diberikan $\mathrm{CCl}_{4}$ menunjukkan peningkatan aktivitas spesifik enzim ALT (Tabel 1). Kerusakan yang terjadi akibat paparan $\mathrm{CCl}_{4}$ disebabkan konversi molekul $\mathrm{CCl}_{4}$ menjadi radikal bebas $\mathrm{CCl}_{3}{ }^{\circ}$ oleh sitokrom $\mathrm{P} 450$. Sitokrom P450 memediasi transfer elektron ke ikatan $\mathrm{C}-\mathrm{Cl}$ membentuk radikal bebas triklorometil $\left(\mathrm{CCl}_{3}{ }^{\circ}\right) . \mathrm{CCl}_{3}{ }^{\circ}$ sangat mudah berekasi dengan oksigen membentuk radikal triklorometil peroksi $\left(\mathrm{CCl}_{3} \mathrm{O}_{2}{ }^{\circ}\right)$ yang lebih reaktif. Radikal bebas $\mathrm{CCl}_{3} \mathrm{O}_{2}{ }^{\circ}$ ini dapat menyerang lipid pada membran retikulum endoplasma menyebabkan peroksidasi lipid sehingga terjadi peningkatan $\mathrm{OH}$ dan $\mathrm{Ca}^{2+}$ sitoplasma interseluler menyebabkan autolisi asam lemak yang terdapat pada fosfolipid membran sel sehingga terjadi peningkatan permeabilitas membran(Gold et al., 2003; Daniel et al., 2004; Panjaitan et al., 2007; González-Reyes et al., 2013; Dai et al., 2014). Hal ini akan menyebabkan kerusakan bahkan kematian sel hepar. Rusaknya membran sel hepar menyebabkan bocornya proteinprotein dan molekul-molekul lain keluar yang kemudian masuk dalam darah, termasuk protein spesifik yang terdapat pada jaringan hepar seperti enzim transaminase, yaitu enzim ALT, sehingga terjadi peningkatan aktivitas spesifik ALT (Marinda, 2014). Hasil pada penelitian ini sejalan dengan penelitian yang dilakukan oleh Ruqiah dkk (2007) yang menunjukkan bahwa pemberian $\mathrm{CCl}_{4}$ sebanyak 0,$1 ; 1,0$; dan $10 \mathrm{ml} / \mathrm{kgBB}$ yang diberikan secara intraperitoneal mengakibatkan adanya peningkatan aktivitas enzim ALT serum (Panjaitan et al., 2007). Penelitian yang dilakukan oleh Adewale et al (2014) juga menunjukkan bahwa pada $\begin{array}{lllll}\text { pemberian } & 3 \mathrm{ml} / \mathrm{kgBB} & \mathrm{CCl}_{4} & \text { menyebabkan }\end{array}$ kerusakan hepar yang ditandai dengan terjadinya peningkatan kadar enzim hepar dalam serum (Aspartat aminotransferase (AST), Alanin aminotransferase (ALT), dan Alkaline phosphatase (ALP))(Adewale O.B, Adekeye A.O, Akintayo C.O, Onikanni A, 2014).

Tabel 1 menunjukkan penurunan aktivitas spesifik enzim ALT antara pretest dan posttest pada kelompok III-VI. Pemberian kurkumin (Kelompok III) menunjukkan adanya penurunan aktivitas spesifik enzim ALT ke rentang normal. Hasil penelitian ini sejalan dengan penelitian yang dilakukan Naglaa dan Eman (2014) yang menunjukkan bahwa pemberian $300 \mathrm{mg} / \mathrm{kgBB}$ kurkumin efektif dalam memperbaiki fibrosis hepar yang ditunjukkan oleh penurunan kadar ALT, AST, dan bilirubin total ke rentang normal (Khedr and Khedr, 2014).

Radikal bebas yang terbentuk dalam tubuh dapat dinetralisir oleh mekanisme pertahanan antioksidan endogen, apabila terdapat dalam jumlah yang tidak berlebihan. Antioksidan merupakan suatu senyawa yang pada konsentrasi rendah secara signifikan dapat menghambat atau mencegah oksidasi substrat dalam reaksi rantai. Antioksidan akan mendonorkan elektronnya kepada molekul radikal bebas, sehingga radikal bebas menjadi stabil (Werdhasari A, 2014). Antioksidan dibagi menjadi antioksidan endogen, seperti superoksida dismutase (SOD), katalase (Cat), gluthathione peroxidase (Gpx), serta antioksidan eksogen, yaitu yang didapat dari luar tubuh, seperti kurkumin dan andrographolide yang digunakan dalam penelitian ini.

Kelompok IV- VI menunjukkan bahwa pemberian andrographolide dapat menurunkan aktivitas spesifik enzim ALT ke rentang normal $(\mathrm{p}<0,05)$. Penelitian terdahulu yang dilakukan oleh Visen dkk tahun 1993, menunjukkan andrographolide pada dosis $0,75-12 \mathrm{mg} / \mathrm{kg}$ yang diberikan secara per oral selama 7 hari memiliki aktivitas signifikan terhadap toksisitas hepar tikus yang diinduksi parasetamol (Visen et al., 1993). Penelitian yang dilakukan oleh Guojun, et al (2012) menunjukkan bahwa dengan pemberian 30 dan 100 $\mathrm{mg} / \mathrm{kg}$ andrographolide secara intraperitoneal 2 jam sebelum pemberian Concanavalin-A dapat mengurangi aktivitas serum ALT secara signifikan. Pemberian andrographolide juga dapat menurunkan produksi ROS (Reactive Oxygen Spesies) dan mengurangi stress oksidatif di hepar yang ditunjukkan dengan penurunan aktivitas serum lactate dehydrogenase (LDH) dan myeloperoxidase (MPO) (Zhang et al., 2012).

Penelitian lain yang dilakukan oleh JuFeng, et al (2011) menunjukkan pretreatmen 100 $\mathrm{mg} / \mathrm{kg}$ andrographolide dapat secara efektif mencegah kerusakan hepar yang diinduksi $\mathrm{CCl}_{4}$ dengan menginhibisi stress oksidatif dan respon inflamasi yang ditunjukkan melalui penurunan aktivitas spesifik serum AST dan ALT serta malondialdehid (MDA) hepar. Pemberian andrographolide juga secara signifikan menghambat deplesi dari glutathion (GSH) di hepar. Hal ini mengindikasikan bahwa andrographolide merupakan penangkal radikal dan memiliki efek perlindungan terhadap hepatotoksisitas yang diinduksi $\mathrm{CCl}_{4}$ (Hu et al., 2011).

Andrographolide tergolong kedalam antioksidan pemutus rantai peroksidasi lipid. Pada struktur andrographolide terdapat hidrogen alilik pada atom karbon C-11 yang memegang peranan penting dalam memutuskan peroksidasi lipid. Andrographolide mendonasikan hidrogen aliliknya untuk berpasangan dengan elektron tak berpasangan dari radikal bebas (Chao and Lin, 2010). Dalam menangkal radikal bebas yang terbentuk akibat paparan $\mathrm{CCl}_{4}$, andrographolide dapat mengeleminasi pengaruh kereaktifan $\mathrm{CCl}_{4}$ dengan menurunkan energi ikatan antara radikal bebas dengan reseptor yang ada dalam hepar (Hu et al., 2011). 
Hasil pada kelompok VI menunjukkan penurunan aktivitas enzim ALT paling tinggi, dibandingkan kelompok IV dan kelompok V dengan $\mathrm{p}<0,05$ (Tabel 1). Sehingga dapat disimpulkan bahwa dosis efektif andrographolide ialah dosis 200 $\mathrm{mg} / \mathrm{kgBB}$. Efek yang ditunjukkan pada pemberian $200 \mathrm{mg} / \mathrm{kgBB}$ andrographolide sama dengan pemberian $500 \mathrm{mg} / \mathrm{kgBB}$ kurkumin (Kelompok III).

\section{IV.Kesimpulan}

Induksi $\mathrm{CCl}_{4}$ dosis toksis menyebabkan kerusakan hepar yang ditandai dengan peningkatan aktivitas ALT serum. Pemberian andrographolide menunjukkan adanya efek hepatoprotektor yang dibuktikan dengan penurunan aktivitas alanain aminotransferase (ALT) pada tikus putih jantan galur wistar yang diinduksi $\mathrm{CCl}_{4}$ dengan dosis efektif $200 \mathrm{mg} / \mathrm{kgBB}$ yang setara dengan kurkumin dosis $500 \mathrm{mg} / \mathrm{kgBB}$.

\section{Daftar Pustaka}

Adewale O.B, Adekeye A.O, Akintayo C.O, Onikanni A, S. S. (2014) 'Carbon tetrachloride $(\mathrm{CCl} 4$ )-induced hepatic damage in experimental Sprague Dawley rats: Antioxidant potential of Xylopia aethiopica', The Journal of Phytopharmacology, 3(2), pp. 118-123.

Chao, W.-W. and Lin, B.-F. (2010) 'Isolation and identification of bioactive compounds in Andrographis paniculata (Chuanxinlian)', Chinese Medicine, 5(1), p. 17. doi: 10.1186/1749-8546-5-17.

Dai, N. et al. (2014) 'Antioxidant Properties of Proanthocyanidins Attenuate Carbon Tetrachloride $\left(\mathrm{CCl}_{4}\right)$-Induced Steatosis and Liver Injury in Rats via CYP2E1 Regulation', Journal of Medicinal Food, 17(6), pp. 663-669. doi: 10.1089/jmf.2013.2834.

Daniel, S. et al. (2004) 'Through metal binding , curcumin protects against lead- and cadmium-induced lipid peroxidation in rat brain homogenates and against leadinduced tissue damage in rat brain', 98, pp. 266-275. doi: 10.1016/j.jinorgbio.2003.10.014.

Departemen Kesehatan RI (2007) Pharmaceutical Care untuk Penyakit Hati. Jakarta: Departemen Kesehatan RI.

Fujii, T. et al. (2010) 'Mouse model of carbon tetrachloride induced liver fibrosis: Histopathological changes and expression of CD133 and epidermal growth factor', BMC Gastroenterology, 10(1), p. 79. doi: 10.1186/1471-230X-10-79.

Gold, E. J. et al. (2003) 'Changes in activin and activin receptor subunit expression in rat liver during the development of CCl4induced cirrhosis', Molecular and Cellular Endocrinology, 201(1-2), pp. 143-153. doi: 10.1016/S0303-7207(02)00417-3.

González-Reyes, S. et al. (2013) 'Curcumin pretreatment induces Nrf2 and an antioxidant response and prevents hemininduced toxicity in primary cultures of cerebellar granule neurons of rats', Oxidative Medicine and Cellular Longevity, 2013. doi: $10.1155 / 2013 / 801418$.

Hu, H. Z. et al. (2011) 'Protective Mechanism of Andrographolide against Carbon Tetrachloride-', 34(11), pp. 1666-1670.

Khedr, N. F. and Khedr, E. G. (2014) 'Antioxidant and Anti-inflammatory Effects of Curcumin on CCl4 â?" induced Liver Fibrosis in Rats', American Journal of Biomedical Sciences, 6(3), pp. 191-200. doi: 10.5099/aj140300191.

Kumar, V., Abbas, A. K. and Aster, J. C. (2013) Buku Ajar Patologi Robbins. 9th edn. Edited by I. Nassar and S. Cornain. Jakarta: Elsavier.

Marinda, F. D. (2014) 'Hepatoprotective effect of curcumin in chronic hepatitis', J Majority, 3(VII), pp. 52-56.

Panjaitan, R. G. P. et al. (2007) 'Pengaruh Pemberian Karbon Tetraklorida Terhadap Fungsi Hati Dan Ginjal Tikus', Makara, kesehatan, 11(1), pp. 11-16.

Ratner, M. H. et al. (2008) 'The Current State of Serum Biomarkers of Hepatotoxicity The current state of serum biomarkers of hepatotoxicity', (April). doi: 10.1016/j.tox.2007.11.021.

Sherwood, L. (2014) Fisiologi Manusia Dari Sel Ke Sistem. 8th edn. Edited by H. O. Ong, A. A. Mahode, and D. Ramadhani. Jakarta: EGC.

Sonderup, M. W. (2011) '[Drug induced liver injuries].', Canadian Medical Education Journal, 29(6), pp. 244-246. Available at: http://www.ncbi.nlm.nih.gov/pubmed/228 41776\%5Cnhttp://www.ncbi.nlm.nih.gov/ pubmed/8231072.

Torotra, G. J. and Derrickson, B. (2014) Principles of Anatomy and Physiology. 14th edn. Hoboke: WILEY.

Werdhasari A. Peran Antioksidan Bagi Kesehatan. Jurnal Biotek Medisiana Indonesia. 2014; 3(2): 59-68.

Visen, P. K. S. et al. (1993) 'Andrographolide protects rat hepatocytes against paracetamol-induced damage', Journal of Ethnopharmacology, 40(2), pp. 131-136. doi: 10.1016/0378-8741(93)90058-D.

Zhang, Z. et al. (2012) 'Protective effect of andrographolide against concanavalin Ainduced liver injury', NaunynSchmiedeberg's Archives of Pharmacology, 385(1), pp. 69-79. doi: 10.1007/s00210-011-0685-z. 